\title{
An Essential Picture in a Sketch-Book of Ireland: The Last Hedge Schools
}

\author{
$M^{\mathrm{a}}$ Yolanda Fernández-Suárez \\ University of Burgos
}

\begin{abstract}
Copyright (c) 2006 by $\mathrm{M}^{\mathrm{a}}$ Yolanda Fernández-Suárez. This text may be archived and redistributed both in electronic form and in hard copy, provided that the author and journal are properly cited and no fee is charged for access.
\end{abstract}

\begin{abstract}
The national system of education was introduced in Ireland in 1831, which meant the beginning of the end for hedge schools. Nevertheless, they lasted longer than it is popularly believed and up to the 1870s there were still many parents willing to pay for the education of their children at the native schools. This was due to several reasons: the changing attitude of the Catholic Church towards the new system, the curriculum of the national school, its rules and material conditions, etc. After this date there is hardly any information about them. However, we have found a unique photograph which shows a hedge school still in use in 1892! In spite of being the last native school documented, it does not seem to be so different from the ones that many writers travelling in Ireland reported on earlier in the nineteenth century. In fact, it could vividly depict a scene belonging to preFamine rural Ireland, an essential document in any history of Irish education.
\end{abstract}

Key Words: hedge schools; native schools; elementary education; school buildings; nineteenthcentury Ireland.

\section{Changing attitudes of the Churches towards the National school}

The First Report of the Commissioners of Irish Education Inquiry, published in 1825, showed how the British attempt at using education as a tool of social control -endowing Protestant societies so that they provided elementary education for Catholic lower classes- had had little success. The report concluded that the only alternative to truly educate the population while pleasing every religious denomination would be a neutral, mixed, national system, a solution already pointed out by an earlier Commission in 1812. Therefore, the National School system was set up not only with the aim of achieving the literacy of the lower classes but also "to cultivate good feeling

ISSN 1699-311X between the parties that may have been at variance" while introducing religious education without causing any animosities (Hyland \& Milne 1987: 116). However, as time went by, the pressure of the Churches would make it unworkable and it ended up being non-denominational de facto, though not de iure.

As for hedge schools, they became legal when Catholic Emancipation was achieved in 1829, though their situation did not change much. Lacking an official status, they were considered part of the informal education sector. Certainly, the introduction of national schools meant the beginning of the end for the native system of education. Nevertheless, they still lasted for some years, as we intend to show in the following pages.

To fully understand the competition hedge schools were going to face we must consider that national schools were publicised as 
efficient from an educational point of view, while socially respectable, as they had the support of the government. The Commissioners of the National Board of Education would contribute to the cost of building schools, provide school equipment, establish training schools for teachers and pay teachers' salaries. The fact that their fees were so low must have had a great influence, too, especially for those parents with little or no means. ${ }^{1}$ In return, schools should be under the supervision of a local Committee. In small communities very often Catholic priests ended up being the only ones in charge of distributing the money received from the government, which they did following their own criteria. Therefore, there was a continuity between what Daly considers the "clerically patronised schools" of the 1820s and many National schools of the 1830s: up to $55 \%$ of schools applying to become part of the new system were already in existence earlier (1979: 156). Among these, the majority had been established with the support of the priest or the landowner, only a few were 'private', i.e. established by the teacher himself (hedge schools strictly speaking).

In the beginning, the Catholic hierarchy favoured the National system, assuming that "national" meant being provided with government funding. Money for education would be equally distributed to the representatives of different denominations, and not only to the Official Church as had been happening till then. In fact, when asked in 1824, a Catholic priest had considered that the government support of Catholic hedgeschoolmasters would have solved the pressing problem of educating the vast amounts of Catholic children:

It rests with the government to make their situation something better than it is. If they were provided with a house rent free and $£ 5$ per annum, it could be a matter of great consequence to them; it would enable them to live in comparative comfort, and teach all the very poor children of their neighbourhood

\footnotetext{
${ }^{1}$ And it would be so until 1892 when the Irish Education Act was passed, making education free and compulsory for students between the ages of six and fourteen.
}

gratis. ... I mean a house which would protect the inmates from the rain or from the snow, and which could be erected for $£ 10$ or $£ 15$. The medium through which the money and expenditure should be conveyed is the Catholic Clergy (Brenan 1935: 530).

Catholic leaders, however, saw hedge schools and their masters in a rather different light. Thus, Dr. Doyle, bishop of Kildare and Leighlin, supported the concept of mixed education, among other reasons, because it would mean the end of the hedge-school system, an opinion openly expressed in a letter to the priests of his diocese in 1831:

[The Roman Catholic bishops] welcomed the rule which requires that all the teachers henceforth to be employed be provided from some Model School, with a certificate of their competency, that will aid us in a work of great difficulty, to wit, that of suppressing hedge schools, and placing youths under the direction of competent teachers, and of those only (Hyland \& Milne 1987: 108).

So, generally speaking, the Catholic clergy favoured the system during the first decades and one of their archbishops, Daniel Murray of Dublin, was a Commissioner of national education from 1831 until 1851. It was only John MacHale, Archbishop of Tuam, who vetoed it. He was a passionate nationalist and defender of the Irish language so he fought against the settlement of any national school in his area because there was no provision of Irish and everything was taught through the medium of English (Daly 1979: 151). It was mainly in 1838 when, through several letters, he urged a great transformation of the system, making the population wonder if the National System was really fair for Catholics. He complained that, in order to be so, among the seven members of the Board there should be a majority of Catholics, as they represented the majority of the population. He also disagreed with the fact that the prospective teachers for Catholic students were instructed by Protestant teachers, and not even Irish ones. In his opinion, it was actually an "anti-national" system and, eventually, he was able to bring the controversy to Rome, in 1839 (O'Brien 1885: I, 181).

Meanwhile, Presbyterians and the Official Church were not happy either and were trying to include significant changes in the system. In 1839, in the Synod of Ulster the Presbyterians requested that in that province Catholic priests would be banned from teaching Catholic 
students separately. When in 1840 their request was granted, Catholic parents reacted by taking their children from these national schools, which ended up being Presbyterian in denomination. Later, in 1842, Dr Henry Cooke (considered one of the fathers of Presbyterian Church) complained about what they called the "fifty two Popish holidays" - days for separate religious instruction- and, eventually, they were suppressed. Only from then on did Presbyterians become firm defenders of the National school. MacHale went on with his campaign, calling a meeting in Dublin in 1839 where three bishops for the national system and three against it would set out the Catholic demands, namely, that the Catholic clergy were patrons of their schools, with the power to employ and dismiss teachers as well as to supervise the religious books that their students would use. Although MacHale's popularity was growing in Ireland, the answer from Rome in 1841 was certainly discouraging. Pope Gregory XVI agreed that all the schools founded by the Catholic clergy should belong to the Church but, other than that, he decided to give another opportunity to the National System and ordered the ending of all public debate on the question of education. For their part, in 1845 the Board of Education decided that from then on they would not endow those national schools that would not belong to them.

After the Famine the debate resumed. This time the Catholic clergy used the excuse of the textbooks at national schools, which, according to them, had the aim of denationalising and anglicising the Irish (as Irish history was hardly studied). In 1850 in the Synod of Thurles they changed their attitude towards the national system, condemning it and favouring denominational education for Catholics. Lead by Cardinal Paul Cullen, Archbishop of Dublin from 1852, the Catholic Church was trying to turn the national system into a Catholic one while the Protestant Church was trying to do the same for their denomination. Cullen now insisted on MacHale's arguments that:

A mixed system might do well in a country where the population was mixed but that was not the case in Ireland. In Munster, Leinster and Connaught, the schools of the Board were attended almost exclusively by Catholic. It was only in Ulster that the system could at all fairly be described as mixed (O'Brien 1885: I, 204).
It was obvious, then, that the whole country was opposing the non-denominational system of education. The Official Church ended up creating their own system (Church Education Society) and, eventually, in 1860 the Catholics achieved the same number of representatives in the Board of Education. That is how, in practice, national schools had mainly students from just one denomination, were run according to the interests of this denomination and the teachers were of the same religion as their students.

\section{National school system vs. hedge school system}

Let us now have a closer look at the progress made by the new system and how the native hedge schools coped with it. If the number of schools that became national is anything to go by, the new system seemed to be quite successful at first. The following figures chosen at random from the Thirty First Report of the Commissioners of National Education in Ireland (H.C. 1865: vol. XIX (3496), vi) show its apparent success:

$\begin{array}{cc}\text { Year } & \text { No. of Schools in Operation } \\ 1833 & 789 \\ 1835 & 1.106 \\ 1839 & 1.581 \\ 1845 & 3.426 \\ 1849 & 4.321\end{array}$

However, the new schools were far from being the only option for elementary schooling, as hedge schools and other schools from different Protestant Societies were still in operation all over the country. What is more, the number of hedge schools actually increased, as shown by the data from the Roman Catholic and Protestant returns to the Commissioners of 1824 and 1835 (Brenan 1935: 65). ${ }^{2}$ Different reasons may explain this apparent inconsistency: on the one hand, it could be due to the population explosion in these years; on the other, because only the data from the Protestant clergy were shown in the report of 1835 and they might have considered any Catholic private school as a hedge school; finally, the criteria for the two reports may

2 Brenan is the only scholar who has compared them, although only the ones for Kildare and Leighin, as the records for 1824 with information about the rest of the dioceses were destroyed in the destruction of the Public Record Office of Ireland at the Four Courts in 1922. 
have been different as many teachers who in 1824 were not labelled as "hedgeschoolmasters", received this name in 1835 . Again, possibly, their not belonging to the official system of education would have been enough to be classified as such.

Even a few years later, in 1841, the Census data proved that only a third of children who attended school did so in a national school (H.C. 1843: 413). Therefore, the majority still received their education at hedge schools. Certainly, the Famine marked their decline as the number of students decreased considerably and the families that survived were in such a state of dispossession that they would not be able to afford to pay for the education of their children. If a hedge school was closed the only alternative for its master would be emigration or becoming part of the new system, provided he were accepted. Nevertheless, there were families that still opted for the hedge school even having a national school in the same area. Evidence is abundant in the National School Aided Applications: in 1848 an inspector reports that "there is a hedge school in the area which does no good to the national school" while in 1856 another one informs that "the manager hopes to overcome the ignorant prejudice against national schools among parishioners" (both cited by Hoban 1983: 29). Later on, in 1859 -nearly thirty years after the introduction of the new system- we find another inspector who claims "I find the people have a remarkable predilection for the ordinary hedge school, and hence there is as yet an unwillingness to send their children to the national school" (Hoban 1983: 30).

This attitude of part of the population can only be accounted for by considering manifold perspectives. First of all, from the merely academic point of view, we have to consider that the new system was radically opposed to what the population was used to. As for the curriculum, it was truly one of the features of education that really marked the difference between the native system and the new one. In hedge schools, both rural and urban, elements of elementary education were combined with other of intermediate education. Apart from Classics or advanced Maths, other subjects like Gauging, Navigation, Physics or Book-keeping became very popular. The curriculum varied according to the needs of the community where the school was found and the qualifications of the master. The need for
Grammar Hedge Schools -as these came to be known- arose from the lack of an organised system of intermediate education for the lower classes. ${ }^{3}$ In fact, there is evidence that shows that some hedge-schoolmasters who had become part of the national school system did not follow the rules laid down by the Board of Education. An inspector visiting a school in 1835 found out when examining the pupils that:

Amazed at the skill of the twelve year old boys in reading the new books, and considering the possibility that they were reciting from memory, I invited one of their number to read me a passage from the gospel of Saint Matthew. Evidently the child misunderstood me. He searched in his satchel until he found his tattered book, stood up, and proceeded to read me the account of Christ's passion -in Greek (Local Ireland \& Others 1999). ${ }^{4}$

The population did not agree at all with the education given at national schools on account of this lack of intermediate education, which they considered a national disaster. The inhabitants of Newtownsteward, Co. Tyrone provide us with an invaluable example of this attitude. They addressed a letter of complaint to the Commissioners of National Education, accusing the new system of causing their community a great loss as they had caused the end of "the previously existing means of Intermediate Education". They were not appealing for Intermediate schools, they merely wanted -as had been happening till then- "to allow an Intermediate element to combine itself locally with their primary instruction" (both Corcoran 1928: 180-183).

The truth is that the Board of Education never intended to introduce intermediate education in their curriculum. On the contrary, they deliberately lowered the standards that popular education in Ireland had had till then. At least that is what a pamphlet (written in 1857, never published but which circulated

3 Quane (1954) calls them "Hedge Grammar Schools" while O'Connell opts for the term "Classical Schools" as the main studies were Classics and Maths (1942: 262-65, 268). Curtin (1935: 299) chose "classical and vernacular Irish schools". I have decided on "Grammar Hedge Schools" because I consider them a higher class of the common hedge school.

${ }^{4}$ From the papers of the Archdeacon of Fern. 
privately) claims about the educational policy followed by the leading class:

... there is at present a deplorable and increasing want. I speak not of schools for the upper classes, but for the middle and lower middle through the country and in smaller towns. The very success of the National Board has proved a calamity. It has destroyed the means by which they could keep their grade, or hope to ascend a step in life. The schools which preceded the Board, even down to the Hedge Schools, however glaring their general deficiencies, had a classical department. It supplied a genuine want, by opening the door, upwards, to the intelligent and industrious of every class; and thus had no mean effect in nurturing the ability and diligence of the people (Curtin 1935: 304). ${ }^{5}$

And not only was the teaching of Maths or the Classics gradually and systematically neglected from 1831 onwards, but the Board also promoted the teaching of new subjects like agriculture, domestic economy (for girls) or industrial instruction (for boys). These subjects were genuinely believed to be more adequate for the lower classes as the Commissioners clearly stated in their Fourth Report that the national school should aim at "bring forward an intelligent class of farm labourers and servants" (H.C. 1837-38: vol. XXVIII (110), 46). The patronizing opinion that certain academic standard among lower classes would only cause trouble was also shared by the Catholic hierarchy. Even Cardinal Cullen, though opposing the Commissioners and critical of their work, firmly believed that the basis of their plan was satisfactory. His letter to the Powis Commission $^{6}$ is memorable in this respect:

I would teach the children to read and to write and to cipher as far as the rule of three and practice; and I would give them a practical and well founded knowledge of the doctrines and duties of religion and some little account of the history of the scriptures and the Church.

\footnotetext{
5 "A Letter to the Right Rev. the Lord Bishop of Derry and Raphoe, on the Present State of the Education Question", it covers 22 pages, the above mentioned paragraph is part of the conclusion.

6 This commission was instructed in 1868-70 to inquire into the construction and working of the National Board. They amassed evidence on the classification and promotion of teachers, the methods of inspection, pupil attendance levels, etc. The many recommendations they made influenced the way national education developed from then on.
}

I would not compel them to enter into discussions on grammar or the Greek roots or mammalia or marsupialia and other classes of animals and similar questions that are not necessary for the poor people. Too high an education will make the poor often times discontented and will unsuit them for following the plough or for using the spade or for hammering iron or building walls (Logan 1990: 130).

Therefore the inspectors and the leading classes, in general, were perplexed when they became aware that these new studies were not appealing for parents nor students. This was so because for the lower classes the concept of "education" meant "bookish learning" and not activities similar to what they already did in their daily lives at home. Thus, despite so many adverse conditions, the data from the Census for the decade 1861-71 showed that "the Roman Catholics wholly dependent upon voluntary effort, and, at the same time, the least wealthy of the population, have increased the number of pupils receiving intermediate instruction in the ratio of 2-5 per cent" (O'Brien 1885: II, 316).

Apart from the curriculum, the calendar and timetables of the national school did not cater for the needs of the parents: students up to fourteen were expected to attend classes on a daily basis, which always caused conflicts with parents, who would withdraw their children from school to help the family in seasonal work. Hedge schools, however, were more flexible: on the one hand, their fees, often paid in kind and different according to the subject (i.e. 1 shilling, 8 pennies for Writing, 2 shillings for Reading, etc) would adapt better to what the parents needed; on the other, they had evening classes for adult learners who had stopped going to school in order to start working.

Furthermore, from the beginning of the nineteenth century a new kind of instruction had become more and more popular: the monitorial system also known as "mutual instruction", ideal for giving instruction to big groups of students with a small number of teachers. The teacher himself did not teach but only supervised the work of the monitors, who were usually the older students in the class and taught their younger classmates following well-drilled directions. This system had first been adopted by the Kildare Place Society and the National Board favoured it for some time. This was the only way in which a teacher 
could be in charge of around one hundred students in just a classroom that was not bigger that 40 feet long (Ó Mórdha 1964: 261). Though a kind of monitorial system was also in use at hedge schools, instruction, however, was far more personalised, a fact favoured by the parents.

On the other hand, there were more subtle reasons for the people's predilection for hedge schools. These motives were connected with the rules and regulations of the new system and were first pointed out by Scally in his analysis of the little success of the national school in Kingwilliamstown (Munster) (1995: 145-49). ${ }^{7}$ Although his conclusions refer to this national school specifically, there is no doubt that they could also apply to other government schools. As we have mentioned before, according to the directions of the Stanley Letter, ${ }^{8}$ the national system intended to transfer the control of education to a local representative. In many cases this would be the resident engineer, a person in charge of collecting rents and giving employment to the peasants and who, therefore, represented the interests of the landed gentry and the clergy. Now, with his new responsibility he would become the school inspector. This meant that, apart from deciding which teacher he was going to employ, he would also enforce the strict rules imposed by the National Board of Education. He would have to supervise, among other things, pupils' attendance, the paying of fees, discipline in class, etc. As for discipline problems, we can not overlook the fact that parents were blamed for any misbehaviour of their children. Serious offences were communicated to the priest, who made them public in Sunday mass so that the culprit received punishment in front of the whole community. Consequently, by sending their children to the national school, parents risked putting their lives under the inspector's control. As most of the population was formed

\footnotetext{
${ }^{7}$ This school opened in 1836 but its expectations of enrolling the 84 students of the area under fourteen in any of the five courses they offered was never even remotely achieved.

8 Named after Lord Edward Stanley, Chief Secretary, who first introduced the national education system. This letter was addressed to the Duke of Leinster in October 1831, inviting him to become the president of the Board of Commissioners for National Education. The whole letter can be found in Hyland \& Milne 1987: 98103.
}

by subtenant farmers, it is only logical to presume that they would not consider such an idea advisable.

Regarding the teachers, the guidelines were equally strict and intrusive on their private lives. Among other practical rules, they could not attend fairs or any political meetings; they had to promote cleanliness and good behaviour and serve as an example for students; they were also obliged to have enough copies of schoolbooks sanctioned by the Commissioners to sell to their students at a low price (Hyland \& Milne 1987: 119-20). The punishment for many offences was the immediate dismissal of the teacher, as was the case if he used the school building for other purposes, if he allowed people to visit without the authorisation of the inspector or the priest, if he had books which were not sanctioned by the National Board, or if he accepted presents from his students or their parents.

While there is evidence of several hedgeschoolmasters who tried their luck in the national system, not all who did so stayed for long. It was precisely the pressure that following the National Board rules put on them, making all their movements quite constricted, why some teachers ended up returning to the old hedge-school system, in which they were their own inspectors and managers. To this the problem of teaching Religion must be added. When the school manager was a Catholic priest, he tended to be suspicious of any involvement from Protestants in his school, even in the most absurd matters as shown by the case of a teacher fired in 1850 because he had allowed the Protestant parson to take shelter from the rain in the porch of his school (Hoban 1983: 31). Similarly, another national teacher who had been working for the system since 1841 was dismissed in 1866 because of an argument with the priest during his wife's funeral (Ó Mórdha 1964: 258). It seems obvious that the national teacher had little respect from managers or inspectors while hedge-school teachers were still highly regarded by the community.

Another reason for the slow integration of hedge-schoolmasters in the national system could have been financial. Given the usual dire straits of hedge schools, the salary surely influenced their decision to become national teachers. In the national system teachers were rated in three different levels, according to 
their efficiency, and the downgrading of teachers was not unusual. Of course, their pay would be in accordance to their level. The Commissioners had set salaries fluctuating between $£ 8$ and $£ 12$ in 1834 that were upgraded to $£ 30$ in 1866. Although it is difficult to imagine what this salary would mean for the standard of living of teachers, any of these salaries were usually lower than the fees charged at hedge schools in the 1824 Report, where it was estimated that many earned more than $£ 20$ (Ó Mórdha 1964: 261). ${ }^{9}$ Part of the reason for such low salaries at national schools was that the Commissioners had assumed that the money they had decided on would be only part of the teacher's pay and that the community would also contribute to his fees. However, it did not work like that. Once the status of national school was achieved by a previously existing school, the population showed reluctance to go on paying fees: in a boys' school in Cork the teacher's salary was $£ 20$ paid by the parents but, when applying to the Commissioners to become part of the national system, they were taking for granted that this money would "lessen in proportion to the aid granted by the Board, being considered burdensome" (Daly 1979: 160).

As for the parents, curiously enough, other reasons why national schools were not very appealing to them were very similar to the criticisms received by the native system of education in the first decades of the nineteenth century, such as the state of the buildings used as schools or the qualification of teachers. Although only a third of the cost of the new school and its fitting should be paid by the community, this money proved to be quite difficult to raise. That is why, generally speaking, the physical conditions of national schools were precarious. Evidence from an inspector in 1837 shows that a school in Roscommon "was labouring under disadvantages from want of space and suitable school furniture" (Hoban 1983: 24); in the archdiocese of Tuam as shown in the First Report of the Commissioners on Public Instruction about 40 per cent of chapels were used as schoolrooms during the week, contrary to the commissioners' rules (H.C. 1835: vol.

\footnotetext{
${ }^{9}$ Nevertheless, national teachers had the advantage of having a retirement pension which consisted of a two or three years' salary.
}

XXXIII (45), 606-633). And later on, in 1858, an inspector from the same area reported that 2 per cent of the schools were still "wretched hovels ... the means of ventilation are so bad, the lighting so imperfect, and the earthen floors damp and unhealthy" (Moloney 2001: 18). Thus, the conditions of both hedge and national schools would be similar, which would discourage parents from opting for the new system.

On the other hand, in spite of the rule that all national teachers should do a three-month training course at the Model School in Dublin, the Register of National Schools shows that several teachers still lacked adequate qualifications (Hoban 1983: 24). ${ }^{10}$ Hedgeschoolmasters had been insistently accused of being very ill-qualified due to having themselves been taught in hedge schools, but in 1868 Gerald Fitzgibbon -one of the Masters in Chancery who cannot be considered partial to them- assured that the training of national teachers in the Model School of Dublin was not any better. He also claimed that having inspectors to check on the commitment of teachers to their jobs was not enough to equal the zeal of the old hedge-schoolmasters. Their incentive had been, and still was, the permanent state of competitiveness with the rest of teachers, a stimulus that had disappeared with the new system (Brenan 1935: 90). This meant that any hedge school with a well-reputed teacher would still be able to attract students. We have found a significant example of how the popularity of the hedgeschoolmaster made the population (even the Protestants) support him instead of the National school:

This man Cushin taught in a barn belonging to John Gannon over a period of twenty years, from approximately 1840-1860. He was well thought of by the people, and had the reputation of being a good teacher. He dressed very well and always wore a tall hat. When a national school was opened in the adjoining townland of Cluntymullen early in the fifties, many people in the district, including some Protestant families, refused to send their

10 Register of National Schools, County Roscommon, 1835-52, P.R.O.I. Query No. 4, mentions a teacher that "although trained in the model school was ignorant and inattentive". Other similar situations can be found in National School Aided Applications, County Roscommon.1832-57, pp. 18, 37, 43 . 
children there, and continued to send them to Cushin (MacGréine 1933: 90).

Nevertheless, the process of implementing the national system eventually made inroads into Irish primary education and the Census Report for 1861 shows that the number of national schools for the first time outnumbered hedge schools (Hoban 1983: 32). Little by little the native schools start to disappear from official documents. Therefore, it is very rewarding to see how the Educational Census of 1868 offers a wealth of information about primary education all over Ireland except in Ulster, commenting specifically on them:

Notwithstanding the growth of national and other schools in which the school fee is not more than one penny a week, and the payment of even this small fee is not always enforced, the Constabulary have returned under the name of hedge schools, 117 schools in Munster, 43 in Leinster and 44 in Connaught, the teachers of which depend for their livelihood on school fees. (H.C. 1870: vol VI, xxiv-xxv).

The same report admits reluctantly that: "there are still some poor people willing to pay for the education of their children even when facilities are offered of obtaining a much superior education gratuitously in national and other schools" (H.C. 1870: vol VI, xvii).

\section{The Last Hedge School ?}

In spite of the scarce information about the last surviving hedge schools, we have some isolated data available. Thus, in county Sligo the last one documented was still in use in 1870, which is considered a very late date (Into 2000: 105). ${ }^{11}$ James Hoban seems to be the only scholar who has done some research on the survival of the native system of education, though focusing just in one county, Roscommon. Among other sources, Hoban has compared the data from the Census of several decades setting the limit to his study to 1891 . Though Hoban's conclusions may not be valid for the whole country, at least they can throw some light on what might have happened in the remotest areas of Ireland, the furthest from the influence of the capital. Both Sligo and Roscommon border county Mayo, where the photograph object of our analysis was taken.

11 It was placed in the diocese of Elphin. The average daily attendance was forty three students, though the official enrolment numbers were one hundred and ten.
And this powerful image shows a school which closed in 1893! It must truly represent one of the last native schools, hence its uniqueness.

This graphic document is part of the collection of CR Browne and JM Browne. All the photographs were taken to scientifically illustrate a scholarly paper on ethnography which was being researched in August 1894. The author, Charles R Browne MD MRIA, read the paper entitled The Ethnography of The Mullet, Inishkea Islands, and Portacloy, Co. Mayo before the Royal Irish Academy in Feb $1895 .^{12}$ Under the photograph there is a handwritten caption: "Hedge School near Gorick. In use 1892, now replaced by Government School". In this case the photographer served as a witness of a hidden Ireland that nobody else would ever see again. And it is precisely the identification of the actual place where it was taken which is one of the first problems the photograph posed for us as no such place exists in the index of townlands and towns of Ireland based on the Census for the year 1851 .

Considering that the Ordnance Survey had taken place in the $1830 \mathrm{~s}$, it was unlikely that the place name had changed later. As the toponym is handwritten, it might be read differently (Corick, Garick or Carick for example) or there might have been some mistake in its spelling. Knowing by the title of the paper that it was located in a specific area in north county Mayo, we tried to find the place in a nineteenth-century atlas (Lewis, Atlas 1837). As it is, there was a town called Carrig, but when we checked this name in the topographical dictionary by the same author, again no such place existed. The only one with a similar spelling was one called Corrick or Corrig-bridge. And this time its description seemed to fully agree with our previous data:

A village, in the parish of Kilcommon, Barony of Erris, Co. of Mayo, and province of Conaught, 16 miles (E.) from Belmullet [...] This village is situated on the road from Crossmolina and Castlebar to Belmullet, and on the river Corrig or Owenmore, over which is a bridge of four arches, from which it takes

\footnotetext{
12 It was published that same year in Dublin by University Press. The volume contains 25 photographic prints and 22 photolithographs. The original photo is from Album 187.
} 
its name; it is a constabulary police station (Lewis, Dictionary 1837). ${ }^{13}$

County Mayo is the third largest county in Ireland (2,156 sq. miles). While the central part of the country contains some of the most fertile land in Connaught, the western region -where the photo was taken- is largely barren, as the lands close to the sea are very bleak and exposed to the western blasts. The parish of Kilcommon was apparently quite extensive and densely populated, with 13,667 inhabitants. There were apparently several interesting archaeological remains such as the ruins of an ancient abbey, a monastery, an ancient burial ground, a druidical altar, etc. These facts seem to indicate that, in spite of being a poor area, there had always been some kind of underlying cultural undercurrent.

In the Roman Catholic divisions, the parish formed the three districts of Ballycroy, with an old thatched building used as a chapel; Kilcommon West with a chapel built in 1832 by subscription; and Kilcommon East, of which the chapel was at Bangor. In contrast to the scarcity of buildings for religious worship, there were fourteen schools that provided up to 450 students with the means of education (Lewis Dictionary, 1837: 67). And all of them were run by private enterprise, which clearly points to hedge schools.

Analysing the outside of our building, we can see a run-down thatched hut following the tradition of "vernacular" rural architecture. Irish cottage-builders used local materials, including stone, clay, sods, grass, and straw and the exterior was often whitewashed. In this particular case, we notice its stone walls and thatched roof. The side walls are quite wide and perfectly laid down in the ground. As was customary, the builders have taken advantage of the split-level in the terrain. What in earlier times could have served to hide the presence of an illegal school (depending on the point of view of the passer-by) was also a natural way of protecting the place from the worst weather conditions, making its heating more economical. Similarly, the orientation of the building collaborates in this protection from both the rain and strong winds that blow in this area close to the Atlantic Ocean: it is orientated facing the sun and that's why the front of the

13 However, under the entry for "Kilcommon Parish", again, the name of our village has a different spelling: Carrick. house is more open -with a window with a wooden shutter and the door- also wooden. It is unlikely that there would be any openings at the back.

As for its interior, we can only imagine what it would be like using information from descriptions of other hedge schools throughout their existence. Apart from seeing if this native school would be a regular hedge school or somewhat exceptional, the comparison will also provide us with a more accurate picture of how life was like in those times.

We will first consider the Irish names for the native schools (Ó Suilleabháin 1963: 159), as they usually refer to their physical characteristics. Apart from the literal translation for "hedge school", scoil scairte, which refers to its clandestine history, when classes were in the open air, we have names like scoil chois clai (school close to a wall or a ditch), scoil mota (school by a moat); scoil fóidin (school by a small plot of land, a sod of turf) alluding to the fact that the teacher usually needed to work the land to survive. ${ }^{14}$ Ours seems to be a "ditch school". The tradition of building the school by a ditch was well-established long before the Penal Laws, as shown in this example during the reign of Charles II:

Stephen Gelosse, S. J. has been working in and near New Ross this year 1669, and ever since $1650 \ldots$ When Cromwell's tyranny ceased, Father Gelosse ... taught a small school ... in a wretched hovel beside a deep ditch, and there educated a few children furtively (Corcoran 1928: 62).

In fact, Arthur Young, travelling in Ireland in the $1770 \mathrm{~s}$, claimed that the most appropriate name for them would be "ditch schools", for he had seen many ditches full of scholars (1780: II, 107). ${ }^{15}$ However, we should notice that this term does not mean exactly the same in Hiberno-English as in British-English. In the former it usually refers to a raised bank of earth, excavated from and placed alongside a

\footnotetext{
${ }^{14}$ Two other names do not have any geographical reference: Scoil ghairid/ghearror "short term school" refers to the seasonal existence of some of these schools while scoil taca or "support school" seems to allude to the evening classes for those students who could not regularly attend school.

15 This book was the most influential traveller's account of eighteenth century Ireland and remains an important source of information about both landlords and the peasantry of the time.
} 
drain or stream. It often has a hedge on top, while in standard English a ditch is a trench (Sammon 2002: 67).

A few years later, when education for the Catholics was allowed, classes were given in huts and that is why the native schools also received the name of "cabin schools", similar to the places where the peasants lived:

The cottages of the Irish, which are called cabins, are the most miserable-looking hovels that can well be conceived; they generally consist of only one room; mud kneaded with straw is the common material of the walls; these are rarely above seven feet high, and not always above five or six; they are about two feet thick, and have only a door which lets in light instead of a window, and should let the smoke out instead of a chimney, but they had rather kept it in [because] it warms them, but [it] is certainly injurious to their eyes ... The furniture of the cabins is as bad as the architecture, in very many consisting of a pot for boiling potatoes, a bit of a table, and one or two broken stools; beds are not found universally, the family lying on straw, equally partook of by cows, calves, and pigs (Young 1780: II, 25-26).

The nineteenth century would not change the living conditions of the Irish peasants much. In 1812, after travelling extensively from north to south, east to west, Edward Wakefield noticed that the population who suffered the worst conditions were the Catholics living in the mountainous areas of the North of Ireland (1812: II, 727ff). In 1814, William Shaw Mason ${ }^{16}$ described the native schools he found in Maghera, Co. Derry:

Schoolhouses are in general wretched huts, built of sods in the highway ditches, from which circumstances they are designated hedge schools. They have neither door, window, nor chimney; a large hole in the roof serving to admit light and let out smoke. A low narrow wall of mud, hard baked served as a seat. A hole cut in the mud wall on the south side affords ingress and egress to its inhabitants. These schools are fully attended in summer, half empty in spring and harvest time; and from the cold and damp utterly deserted in winter; so that the children, who periodically resort to them for instruction, usually forget in one part of the year what

${ }^{16}$ His work, A Statistical Account, or Parochial Survey of Ireland, was compiled from submissions by Protestant Clergy and published in three volumes in 1814, 1816 and 1819. they have learned in the other...(cited by Johnston 1969: 37).

The situation of the poor was aggravated in 1822 when a period of recurrent famine started. The rural population started moving to the towns looking for work. But jobs were difficult to find and they ended up resorting to charity. In fact, in the so-called "distressed districts" (Cos. Cork, Kerry, Limerick, Galway, Mayo, Sligo, Leitrim, Roscommon, Clare and part of Tipperary) more than half of the population subsisted through charity, around three million out of a total population of seven million people according to the Census of 1821 (O’Brien 1885, I, 540). Later on, during the Famine years we find a document of how the most destitute among the peasants lived in "semi-underground dwellings" built into the side of an embankment, made of unmortared stone and turf (Scally 1995: 120). ${ }^{17}$

Once the National school system was introduced in 1831 descriptions of native schools become more scarce. Nevertheless, in 1846 an inspector in the Strokestown district (Co. Roscommon) found "five or six cabin schools in the neighbourhood attended by about thirty each" (Hoban 1983: 28). And this is not an isolated example. What is most shocking is that, contrary to what could be expected, the material conditions in the native schools were very often similar to the ones of earlier times. We have the evidence given by a student born in 1858, describing the hedge school he attended during the decade from 1860 to 1870 :

The last hedge-schoolmaster I mind was Peter Ursin of Cavany. He taught in a thatched mud-wall cabin just inside Mac Kiernan's lane. The site was immediately below the road and in wet weather was often flooded. From 10 to 12 scholars used to attend it, and I was one of them... many a time I was sent out to the hedge to cut a pointer. Most of us brought a "creepy" stool to sit on, but others just sat on a stone with a bag on it (Ó Mórdha 1964: 257). ${ }^{18}$

All things considered, our school seems to compare quite favourably with the schools existing in the eighteenth and

\footnotetext{
17 As shown in a photograph courtesy of Ulster Folk and Transport Museum.

${ }^{18}$ Incidentally, the teacher mentioned here appeared in the Reports of 1824 teaching in another place but in the same parish.
} 
early nineteenth century but this could be due to its late existence: its stone walls and thatched roof seem to give it a look of certain status; it also boasts a window with a proper shutter (while in other schools old cloths were used to cover them). These seem to indicate that this educational establishment was one of a higher category, probably a grammar hedge school. Although they were not so common as the regular native schools, an Irish folklorist and shrewd observer of the countryside, Crofton Croker, left us a detailed description of "a Kerry college, as it was called locally" in the hills of Killarney in 1824:

The roof displayed -stuck between its scraughs and thievauns - an ample stock of coverless copybooks, slates and gray goose quills, with two or three pendant racks of branchy fir, for the benefit of such pupils as had either caps or hats to hang upon them. The interior of the whole cabin wore a black laquered appearance, conferred upon it by the smoke of many a winter's fire; [...] At each side of the door was a little window about a foot square. But, on the whole, Mr. Casey's college was rather a respectable edifice of the description; for it could boast two real deal forms, and instead of turf branches there were three fir spars placed along the wall, each end supported by stones, in order to elevate the students to a comfortable sitting height. There was, moreover a table for the use of writers and ciphers. Of all these accommodations $\mathrm{Mr}$. Casey seemed not a little proud, as he sat on a rush-bottomed chair, which he facetiously termed his Sanctum Sanctorum (cited by O’Hanlon 1931:156-57).

There is no way of knowing how the interior of the school in the photograph might have been. As Croker's example is an early one and comes from a wealthier area, it cannot help us much. We know, however, that the ground-plan of cottages usually included a door opening onto a central room, which had the hearth as its social and working centre. In the case of school buildings this would often be the only room. At the door we can see some steps to prevent visitors from bringing mud or dirt inside the room, whose floor must have been earthen, probably covered by straw that should be removed often. Although we can not see a chimney, the thatched roof would allow part of the smoke out. As for school equipment, if anything, a slab would be used as a blackboard to write. There would be probably just one "proper" seat, the teacher's, placed near the hearth, and the students would sit on stones covered with moss to make them more comfortable. The students would be seated around him, as shown in one of the illustrative etchings in Carleton's tale of a hedge school (Hayley 1990: I, 271). ${ }^{19}$

\section{Conclusion}

The reason why our school continued in use for so long might have been precisely because of its "good" conditions for those troubled times both from the material point of view and the curriculum it might have taught. Anyway, for us this photograph is a most valuable document at various levels. First of all, from an academic point of view. We are used to finding representations of Ireland by Victorian travellers and tourists who give us but an outsider's perspective and an amateur one at that. This photograph, however, was not taken while on leisure travel, but by an Irish scholar with a scientific purpose in mind so it provides us with an insider's look and a more objective vision than any by a foreigner. It has, then, an informational interest, apart from the aesthetic one.

Secondly, the information it conveys is relevant for any study of education in nineteenth-century Ireland as what this image depicts goes against most studies on the native system of education. Contrary to popular belief, it proves that hedge schools continued to exist till a very late date in spite of the National system of education implemented from the 1830s. Of course, they would never be so numerous as before but they still retained their influence with the parents, and that was the underlying reason for their preservation.

Thirdly, considered from an ethnographic perspective, it also gives rich evidence of the living conditions in rural Ireland at the turn of the nineteenth century, but not only in the area or at the time where it was taken. As it comes

\footnotetext{
${ }^{19}$ This is where I first saw it. However, it is also the cover picture for McManus's book (The Irish Hedge School and Its Books, 1695-1831) and the acknowledgement section says it comes from the title page in The Child's New Spelling Primer; or First Book for Children (1799)
} 
from a remote place where progress took longer to reach, it can well represent what life in parts of the country might have been like in the mid-century or even before that. In fact, we have shown how this photo could go with any of the descriptions by different observers of hedge schools from the beginning of the century. From this point of view, it helps to illuminate the past.

In summary, this documentary image sheds a powerful light on the survival of hedge schools. It would have been like a dream come true for the German traveller Johan Köln who, after describing what he must have considered one of the last specimens of native schools in 1843, stated:

It was, in truth, a touching sight. The schoolhouse was a mud hovel, covered with green sods, without windows or any other comforts. The little pupils, wrapped up as well as their rags would cover them, sat beside the low open door, towards which they were all holding their books in order to obtain a portion of the scanty light it admitted. Some of the younger ones were sitting or lying on the floor; behind these, others were seated on a couple of benches formed of loose boards; and behind these again stood taller children, also holding their books towards the light between the heads of the front rank. The master ... was seated in the midst of the crowd. In a sketch-book of Ireland this would be an essential picture, and I regret I had not a Daguerrotype with me to perpetuate the scene. Outside, before the door, lay as many pieces of turf as there were scholars within, for each one had brought a piece with him as a fee or gratuity for the schoolmaster... The schoolhouse stood close by the roadside, but many of the children resided several miles off, and even the schoolmaster did not live near it (O’ Connor 1948: 44-46).

\section{Works Cited}

Brenan, Martin. 1935. Schools of Kildare and Leighlin, A.D. 1775-1835. Dublin: Gill \& Son

Browne, Charles R. 1895. The Ethnography of The Mullet, Inishkea Islands, and Portacloy, Co. Mayo. Dublin: University Press

Corcoran, Timothy. 1928. Selected Texts on Education Systems in Ireland from the Close Of the Middle Ages. Dublin: UCD

Curtin, Dermot. 1935. "The hedge schools: Dr P. Dowling's History of their work". The Catholic Bulletin. vol. XXV, Apr., pp.299-304.

Daly, Mary. 1979. "The Development of the National School system, 1831-40". Studies in
Irish History. Eds. A. Cosgrove \& D. McCartney. Dublin: University College. 150163

1984 (1861). General alphabetical index to the townlands and towns, parishes and baronies of Ireland. Based on the Census of Ireland for the year 1851. Baltimore: Genealogical Publishing Co.

Hoban, James. 1983. "The Survival of the Hedge School, A Local Study". IES. 3:2. 21-36

Hyland, Áine \& Kenneth Milne. eds. 1987. Irish Educational Documents. Vol I (A Selection of Extracts from Documents Relating to the History of Irish Education from the Earliest Times to 1922). Dublin: CICE

Hayley, Barbara. ed. 1990. Traits and Stories of the Irish Peasantry. 2 vols. Gerrards Cross: Colin Smythe Limited

INTO Millenium Committee, Co. Sligo. 2000. National Schools of County Sligo, 1831-1999. Sligo: Carrick Print

Johnston, John. 1969. "Hedge Schools of Tyrone and Monaghan". Clogher Record. vol. VII. No. 1. 34-55

Köln, Johan Georg. 1844 (1843). Travels in Ireland. London: Bruce

Lewis, Samuel. 1837a. Lewis's Atlas comprising the counties of Ireland and a general map of the kingdom. London: Lewis \& Co.

1837b. A Topographical Dictionary of Ireland, with Historical \& Statistical Descriptions. London: Lewis \& Co.

Logan, John. 1990. "Sufficient for their Needs: Literacy and Elementary Schooling in the Nineteenth Century". The Origins of Popular Literacy in Ireland: Language Change and Educational Development 1700-1920. Eds M. Daly \& D. Dickson. Dublin: Trinity College Dublin. 113-138.

Mac Gréine, Pádraig. 1933. "Co. Longford hedgeschools". Béaloideas. Dublin. 89-90

O' Brien, R. Barry. 1885. Fifty Years of Concessions to Ireland, 1831-1881. 2vols. London: Sampson Low, Marston, Seasle \& Rivington

O' Connell, Philip. 1942. Schools and Scholars of Breifne. Dublin: Brown \& Nolan

O' Connor, Mary L. 1948. The Hedge Schools of Kerry. Cork: UCC. Unpublished MA.

O' Hanlon, Terence. 1931. "The hedge schools". The Capuchin Annual. 155-58.

Ó Mórdha, Pilib B. 1964. "Notes on Education in Currin Parish". Clogher Record. vol V. N 2. 251-262

Ó Suilleabháin, Séan. 1970 (1963). A Handbook of Irish Folklore. Detroit: Singing Tree Press 
Quane, Michael. 1954. "Banna School, Ardfert (With a Prefatory Survey of Classical Education in Kerry in the XVIII Century)". JRSAI. 156-172

Sammon, Paddy. 2002. Greenspeak, Ireland in her Own Words. Dublin: Town House.

Scally, Robert J. 1995. The End of Hidden Ireland: Rebellion, Famine and Emigration. New York: OUP

Wakefield, Edward. 1812. An Account of Ireland Statistical and Political. 2 vols. London

Young, Arthur. 1780. A Tour in Ireland 1776-1779. 2 Vols. Dublin.

Internet resources:

EPPI (Enhanced British Parliamentary Papers on Ireland, 1801-1922): www.eppi.ac.uk (last accessed: 12-01-06)

Parliamentary Papers (or H.C.):

1835. First Report of the Commissioners on Public Instruction. vol. XXXIII (45)

1837-38. Fourth Report of the Commissioners on Public Instruction. vol. XXVIII (110)

1843. Report of the Commissioners appointed to take the Census of Ireland for the year 1841. Dublin: Alexander Thom

1865. Thirty-first Report of the Commissioners of National Education in Ireland. vol. XIX. (3496).

1870. Royal Commission of Inquiry into Primary Education (Ireland). vol. VI. Educational Census 1868.

\section{The Last Hedge School ?}

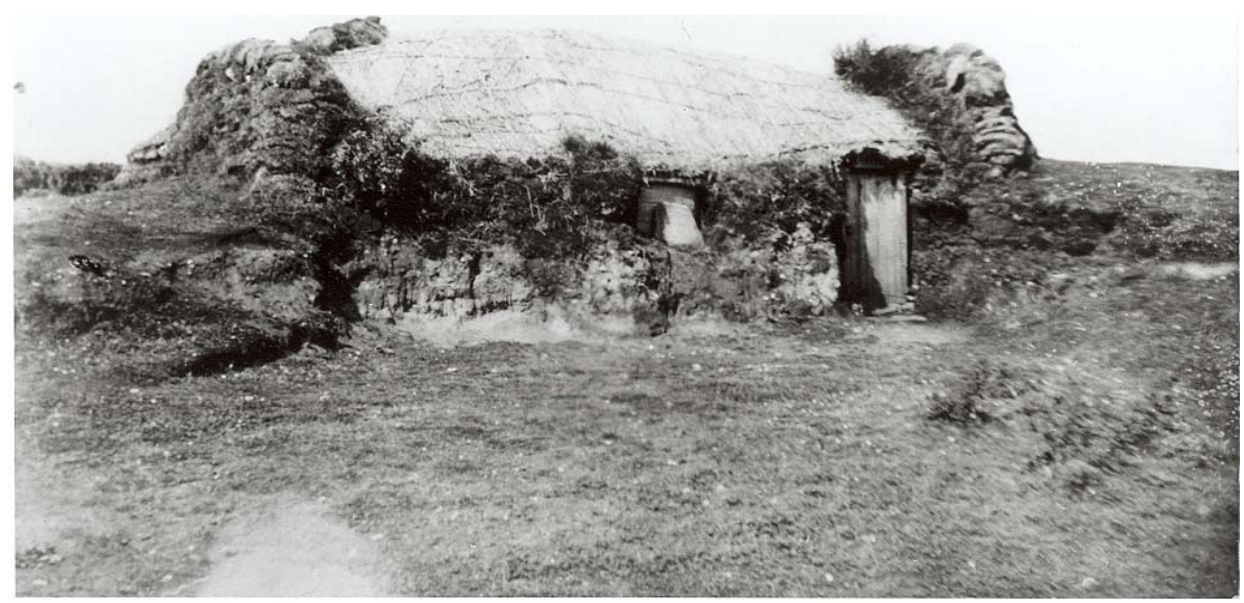

Courtesy of the National Library of Ireland 